\title{
Electrical Energy Production Process from Landfill Gas
}

\author{
Isworo Pujotomo ${ }^{1, *}$ and Septianissa Azzahra ${ }^{1}$ \\ ${ }^{1}$ Electrical Engineering Department, PLN School of Engineering, Jakarta - Indonesia
}

\begin{abstract}
Electrical energy is produced by objects that are electrically charged. Static electric charges will cause electrical potential energy, while dynamic electric charges will cause electric current and magnetic energy. The size of the population and the diversity of activities in metropolitan cities in Indonesia have resulted in general problems in urban infrastructure services, such as current waste problems. Waste is defined as solid waste consisting of organic substances which are considered useless and must be managed so as not to endanger the environment and protect development investment. Landfill gas is a gas produced by solid waste which is disposed of in landfills. The waste is piled up and pressed mechanically and the pressure from the layer above it. Because the condition becomes anaerobic, the organic matter decomposes and gas landfill is produced. This gas is increasingly gathering to be slowly released into the atmosphere and if it is not used or handled properly it will be dangerous because it can pollute the air and the atmosphere of the earth. The largest gas content found in LFG is methane by 45 $60 \%$ and followed by carbon dioxide by $25-50 \%$. Landfill gas is produced from the decomposition of organic waste material.
\end{abstract}

Keywords: Electrical; energy; landfill; gas; methane.

\section{Introduction}

Although this time the backbone of energy in Indonesia still depend on fossil energy. Even various technology applied to the utilization of clean coal as dense medium cyclone, etc [1]. Oil and coal are examples of nonrenewable energy which is still the main source of electricity generation. Non-renewable energy is slowly but surely decreasing in number due to the increasing use and not accompanied by wise consumption patterns. Therefore the use of renewable energy for electricity generation needs to be developed as an optimal and environmentally friendly alternative energy.

Gas Landfill (LFG) is one of the renewable energy sources that can be used as a power plant. The methane gas contained in landfill gas can be used as a turbine player through the combustion process. The use of landfill gas generated from the Waste Disposal Site (TPA) as an electric energy generator is called a Waste Power Plant (PLTSa).

Waste is defined as solid waste consisting of organic substances which are considered useless and must be managed so as not to endanger the environment and protect development investment. The size of the population and the diversity of activities in metropolitan cities in Indonesia such as Jakarta has resulted in general problems in urban infrastructure services, such as current waste problems.

It is estimated that only about $60 \%$ of the garbage in major cities in Indonesia can be transported to the Final
Disposal Site (TPA), whose main operation is $80,235.87$ tons every day, handling $4.2 \%$ of the waste transported and disposed of to landfill is burned $37.6 \%$, which was discharged into the river $4.9 \%$ and not handled by 53.3\%.[2].

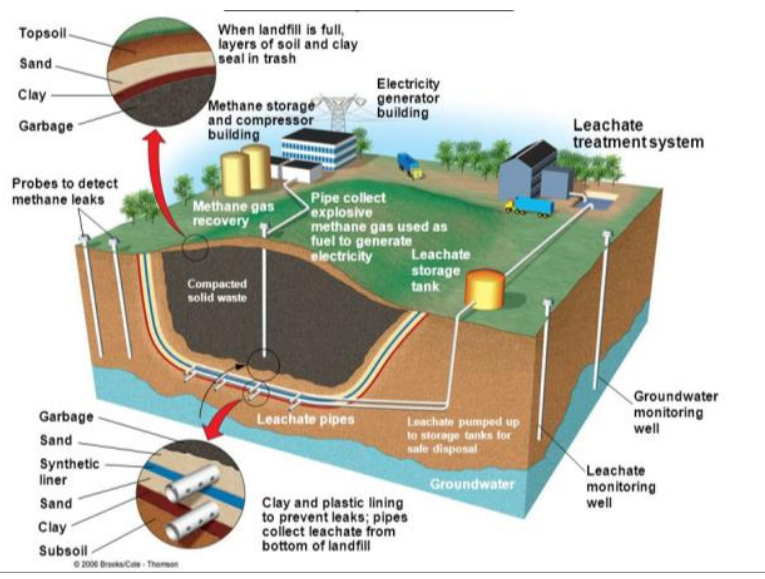

Fig.1. Sanitary landfill

So far, most people still view garbage as useless waste, not as a resource that needs to be utilized. The community in managing waste still relies on the end-ofpipe approach, i.e. waste is collected, transported, and disposed of to the final waste processing site. In fact, large volumes of landfill at the location of the final waste processing site has the potential to release methane

*Corresponding author: isworop@sttpln.ac.id 
(CH4) which can increase greenhouse gas emissions and contribute to global warming. So that waste can be decomposed through natural processes for a long period of time and requires a large amount of handling [3].

Disposal of waste into the land (land disposal) is the most common way in waste management. The way to get rid of waste into the soil by reclaiming or landfilling is known as landfilling, which is applied first to municipal waste. This method was known since the early 1900 s, with the name of sanitary landfills, because the application was concerned with aspects of environmental sanitation.

A simple definition of a sanitary landfill is the method of storing waste into the ground, by spreading waste by layer on a prepared site (land), then compaction with heavy equipment, and at the end of the day of operation, the garbage collection is then closed with land cover.

Waste management in Indonesia mostly still uses sanitary landfill techniques by utilizing methane gas that arises in waste and then channeled via wells and pipes to generate electricity at the site of the final disposal site (TPA). Law No. 18 of 2008 requires that all landfills (TPA) be closed (after 5 years of promulgation, open dumping) into a sanitary landfill. However, in the field, many landfills have been found to be more accurate called controlled dumps without special treatment that has the potential to cause pollution to sources and sources. Data in 2013 showed that landfills operating throughout Indonesia were around 378 (occupying 1900 hectares) which were lower than the number of regencies and municipalities, 81 percent of open landfills, 16 percent of the landfill was controlled, and the rest (3 percent) were sanitary landfills. This means that 305 TPAs of sanitary landfill types must be built immediately to replace the open landfill. In other words, if not going to do the construction of sanitary landfills, the Regency and City must immediately utilize other technologies such as MBT (Mechanical Biological Treatment) followed by $\mathrm{AD}$ or Thermochemical to reduce the amount of old waste already in the landfill while processing environmentally friendly waste into electricity and obtain organic fertilizer as an additional product.

\section{Electrical Energy Conversion from Landfill Gas}

\subsection{Separation and construction of waste}

This process is an initial process to separate the garbage that has been collected by garbage trucks from each landfill (TPS) spread in the big city. Waste that will be produced by landfill gas which will be used for the main fuel of the combustion process to produce electricity. Organic waste is separated to be carried out by landfill which is used as a process for decomposition carried out by bacteria before becoming methane gas [4].

\subsection{Gas production process (decomposition)}

In this process, the waste has been sorted into organic waste and the process of a landfill in the landfill area is ready to be broken down by bacteria. The gas production process begins with the dumping of leftover garbage lying on landfills so that automatically because it is formed mechanically a landfill gas will be produced which is formed due to decomposition activities carried out by bacteria. In principle, the process of forming methane gas through several anaerobic decomposition processes includes hydrolysis, acetogenesis, methanogenesis. In the process of long-chain hydrocarbon methanogenesis decomposed into $\mathrm{CO} 2$ and CH4 (methane) with a composition of $50 \%$ : $50 \%$. The nature of $\mathrm{CO} 2$ dissolves easily in water so that some of the $\mathrm{CO} 2$ is absorbed by water so that the composition changes. The $\mathrm{CH} 4$ content rises between 50 to $60 \%$ so that $\mathrm{CH} 4$ gas can be produced which will be used as fuel for the combustion process by the engine to produce electricity. Gas is channeled by pipes that are available directly on landfills that are directly directed at the engine to do the combustion process to produce electrical energy.

\subsection{Process of delivering gas to the engine}

The gases produced from this landfill are channeled by media that is directly connected by the engine, namely by using a pipe. This pipe takes methane gas which is trapped in a pile of garbage that has broken down in the landfill area. The methane gas contained in this landfill is about $50 \%$ of methane gas and the rest is carbon dioxide $(\mathrm{CO} 2)$ gas. This pipe extends along a very large waste disposal area so that the gases produced can be channeled to the engine in the form of methane gas ready for the combustion process. The initial stage of the gas distribution process starts from methane gas that enters through the landfill pipe through the aid of a blower so that the methane gas enters through the pipe. Then, the methane gas that rises up through the pipe passes through a filter so that the methane gas is cleaner and the water content contained in the air decreases. The excess methane gas that enters will be burned in flare station so that the incoming methane gas is in accordance with the capacity of the gas pipeline. After that, methane gas enters the compressor, which aims to reduce the volume of methane gas to become smaller particles so that the temperature of methane gas increases to around $190^{\circ} \mathrm{C}$. with the increase in temperature of the methane gas particles, then enter the cooler (cooler) which serves to reduce the temperature of the gas to be $2-5^{\circ} \mathrm{C}$ so that the water content contained is condensed at this temperature. Then this methane gas enters the second filter which serves to reduce the water content attached to methane gas so that the methane gas is free from the water content that is still contained in methane gas. Then this methane gas undergoes a reheating process that aims to increase the temperature of the methane gas to around $32{ }^{\circ} \mathrm{C}$ and the end result of this air is ready to be burned in an engine that is already connected to the pipe. 


\subsection{Combustion process}

The combustion process that produces power to the engine consists of 4 stages, namely the intake, compression, power, and exhaust processes. The burning process is as follows:

- Intake is a process of entering fuel which is in the form of $\mathrm{O} 2$ and $\mathrm{CH} 4$ gases which are useful as the main fuel for the combustion process on the engine. At this stage the air $\mathrm{O} 2$ and $\mathrm{CH} 4$ mix with sufficient levels for the combustion process.

- Compression is a process of suctioning air-fuel on the engine that is in the form of $\mathrm{O} 2$ and $\mathrm{CH} 4$ gas then continued with the compression process causing the incoming air to experience a change in pressure to be higher so that the gas mixture changes to very explosive.

- Power is an advanced process after the compression process, which is a blasting process caused by increased air pressure $\mathrm{O} 2$ and $\mathrm{CH} 4$ and then given a spark produced by the spark plug which results in a large explosion that pushes it back down the piston.

- The exhaust is the last process in working to produce power. Exhaust is an advanced process of the power process that is removing the combustion results of $\mathrm{O} 2$ and $\mathrm{CH} 4$ gas so that the exhaust gas is not stored in the combustion chamber and discharged by the engine.

\subsection{Converting mechanical energy into electricity}

The engine that works in the combustion process only produces mechanical energy which will be converted into electrical energy. To convert mechanical energy to become electrical energy, this uses a generator that is directly connected to the spinning engine. This generator functions to convert the mechanical motion force produced by the engine in the combustion process of methane gas that has been carried out in the combustion process. This generator is connected directly to the engine which moves translation in the combustion process into rotational motion with the help of a shaft so that it can rotate a generator which then converts mechanical energy into electrical energy. The electricity produced can reach 8-10 MW, but the electricity produced depends on the methane gas produced because the more methane gas is produced, the greater the electrical energy produced. This is an important concern if the energy yield per day wants to remain stable in accordance with what is needed. Because of that, this is a concern that maybe in the future it can be developed if the energy from this gas landfill will be developed for a large scale $[5,6]$.

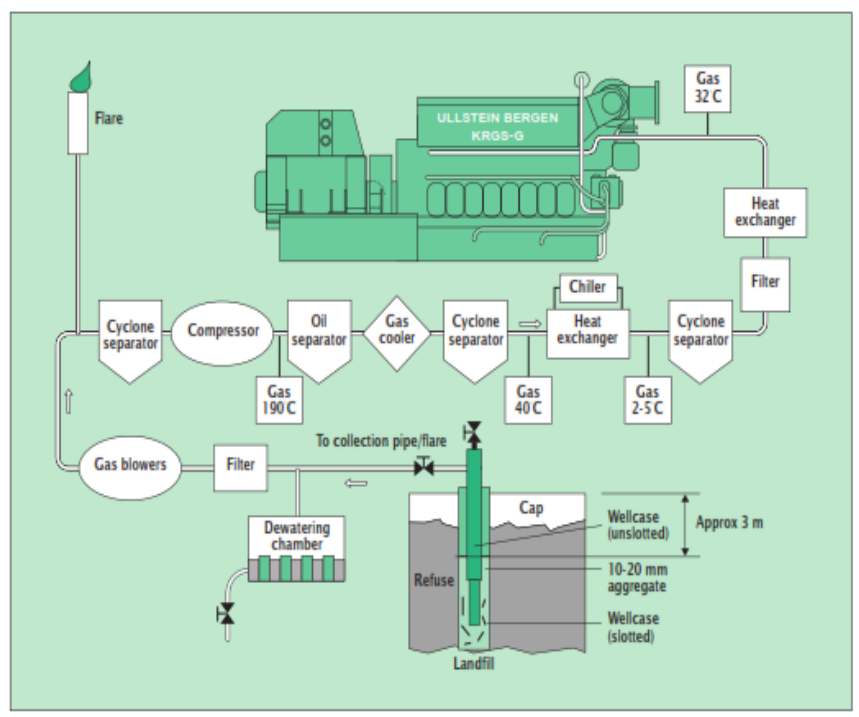

Fig. 2. Schematic of the power station

\section{Advantage and Lack of Landfill Gas}

\subsection{Advantage}

Waste material that is in the waste disposal area can be used as an electric energy generator for domestic consumption. In fact, data obtained from the International Energy Agency shows that several countries have begun to use this type of energy that they get from household and industrial waste that was previously disposed of in a very large amount of waste dumps of more than 400 Terra watts of electricity generated in all over the world, through waste utilization.

Landfills contain large amounts of organic waste such as food scraps, paper, textile, and the rest of the yard. And from that material, it can produce very large amounts of greenhouse gases such as methane and $\mathrm{CO} 2$. A foundation in the United States called the Environment Protection Agency (EPA) says that landfills are the third-largest source of human beings related to methane gas emissions in America, amounting to about $17 \%$ of total methane gas emissions.

With the development of new technology, this makes more sense and makes it possible to use large amounts of methane to produce clean and environmentally friendly electricity. Water and very low $\mathrm{CO} 2$ content can be produced by this process. This process no longer requires more fossil fuels to burn methane because this gas is highly flammable.

Apart from electricity, this new technology also shows that cellulose ethanol can also be produced from this garbage pile. Organically it can be produced due to cellulose degradation found in various organic wastes such as the remaining pieces of grass, pieces of tree twigs and discarded corn stalks and much more. The biofuel produces more energy and reduces greenhouse gas emissions compared to the various biofuels that can be produced today. 


\subsection{Weaknesses}

Burning methane in landfills is a very bad idea. While large amounts of global waste are increasing, a puzzling evidence of methods for harvesting energy from this form is still approved by scientists and policy makers. Experience shows in several places, has shown technology that is more dangerous than profitable. The reason is, the large amount of gas is actually more than the right amount and pollutes the environment which not only contributes to global increases, but also high levels. For example, Methane gas has a $75 \%$ stronger effect on greenhouse gases in its 20 years compared to $\mathrm{CO} 2$.

Most waste disposal areas have been closed at the top to help prevent gas leaks. However, this gas will find another route to escape. For example: an experimental waste dump in Ontario has shown that the potential damage from a gas leak can be far from what can be used to produce electricity around $5000 \mathrm{MW}$ from all of them. Also, the current technology can only process waste from around 20 to $25 \%$ of the total volume of waste present

\section{Result and Analysis}

Landfill gas is a gas produced by solid waste which is disposed of in landfills. The waste is piled up and pressed mechanically and the pressure from the layer above it. Because the condition becomes anaerobic, the organic matter decomposes and gas landfill is produced. This gas is increasingly gathering to be slowly released into the atmosphere and if it is not used or handled properly it will be dangerous because it can pollute the air and the atmosphere of the earth.

Table 1. Percentage for LFG gas

\begin{tabular}{|l|l|l|l|}
\hline No & $\begin{array}{c}\text { LFG } \\
\text { Composite } \\
\text { Gas }\end{array}$ & $\begin{array}{c}\text { Chemical } \\
\text { formula }\end{array}$ & $\begin{array}{c}\text { Percentage } \\
\text { of content }\end{array}$ \\
\hline $\mathbf{1}$ & Methane & $\mathrm{CH}_{4}$ & $40-60 \%$ \\
\hline $\mathbf{2}$ & $\begin{array}{l}\text { Carbon } \\
\text { dioxide }\end{array}$ & $\mathrm{CO}_{2}$ & $25-50 \%$ \\
\hline $\mathbf{3}$ & Nitrogen & $\mathrm{N}_{2}$ & $3-15 \%$ \\
\hline $\mathbf{4}$ & Oxygen & $\mathrm{O}_{2}$ & $0-4 \%$ \\
\hline $\mathbf{5}$ & Hydrogen & $\mathrm{H}_{2}$ & $0-1 \%$ \\
\hline $\mathbf{6}$ & Argon & $\mathrm{Ar}$ & $0-0.4 \%$ \\
\hline $\mathbf{7}$ & $\begin{array}{l}\text { Hydrogen } \\
\text { sulfide }\end{array}$ & $\mathrm{H} 2 \mathrm{~S}$ & $0-200 \mathrm{ppm}$ \\
\hline $\mathbf{8}$ & Chlorine & $\mathrm{Cl}$ & $0-200 \mathrm{ppm}$ \\
\hline $\mathbf{9}$ & Fluorine & $\mathrm{F}$ & $0-200 \mathrm{ppm}$ \\
\hline
\end{tabular}

The table above shows the percentage of LFG constituent gases, it shows that the largest gas content found in LFG is methane by $45-60 \%$ and followed by carbon dioxide by $25-50 \%$. Both methane and carbon dioxide have a role in increasing the warming of the earth's temperature and are categorized as greenhouse gases (GHG). Landfill gas produced at landfills will be dangerous if not managed and controlled properly. The methane gas content in LFG is a flammable gas so the risk of explosion around the landfill site is very high. The effect of methane on increasing global warming is 21 times greater than carbon dioxide. The process of flaring and extraction of methane gas can be done as an effort to reduce methane gas emissions and convert them to $\mathrm{CO} 2$. The formation of landfill gas is through various biological processes. Landfill gas is produced from the decomposition of organic waste material. It is estimated that $1.87 \mathrm{~m} 3$ of landfill gas is produced from every kilogram of decomposed organic matter (to $50 \%$ methane).

\section{Conclusion}

Landfill gas is a gas produced by solid waste which is disposed of in landfills. The waste is piled up and pressed mechanically and the pressure from the layer above it. Because the condition becomes anaerobic, the organic matter decomposes and gas landfill is produced. This gas is increasingly gathering to be slowly released into the atmosphere and if it is not used or handled properly it will be dangerous because it can pollute the air and the atmosphere of the earth.

The process of producing electrical energy from landfill gas through several stages. The first stage is the separation and accumulation of waste, followed by the process of gas production (decomposition). The next stage is the process of distributing gas to the engine, then the next stage is the combustion process, which consists of the intake, compression, power and exhaust processes. The last stage is the conversion of mechanical energy into electrical energy.

\section{References}

1. I. Pujotomo, Clean Coal Technology using Dens Medium Cyclone and Magnetite, American Scientific Publishers ASL 23(3), 2376-2378 (2017)

2. O. Mungkasa, TPA Planning Guidelinesfor Sanitary Landfill Method, http://www.slideshare.net/Oswar Mungkasa/pedoman (2012)

3. E. Damanhuri, Dictation of Waste Landfilling, Bandung Institute of Technology 40 (2008)

4. Ministry of Public Works, Work Unit Price Analysis (AHS) for Public Works in 2008, Badan Litbang Pekerjaan Umum Jakarta (2008)

5. S. Strong, Building Integrated Photovoltaics $(B I P V)$. Whole Building Design Guide. Retrieved 2011-07-26. (2010).

6. O. Temby, K. Konstantinos, H. Berton, D. Rosenbloom, G. Gibson, A. Athienitis, J. Meadowcroft, BIP: DEDFUS. Environment Magazine (2014) 